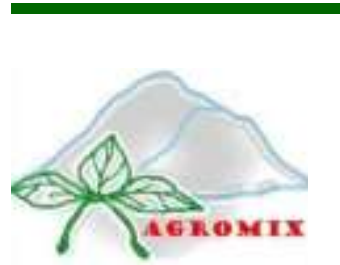

\title{
AGROMIX
}

Jurnal IImiah Fakultas Pertanian, Universitas Yudharta Pasuruan pISSN (Print): 2085-241X; elSSN (Online): 2599-3003

Website: https://jurnal.yudharta.ac.id/v2/index.php/agromix

\section{Efisiensi teknis usahatani kentang pada luas lahan yang berbeda di kabupaten Pasuruan}

Technical efficiency of potatous farming on different land area in Pasuruan regency

\author{
Desy Cahyaning Utami ${ }^{{ }^{*}}$, Wenny Mamilianti ${ }^{1}$ \\ ${ }^{1}$ Program Studi Agribisnis Fakultas Pertanian, Universitas Yudharta Pasuruan, Jawa Timur \\ *Email korespondensi: desy@yudharta.ac.id
}

\section{Article History \\ Received : Mey 5, 2021 \\ Accepted : September 15, 2021 \\ Published : September 28, 2021 \\ Keyword \\ Agricultural land area; \\ pasuruan; potatoes; technical efficiency}

\section{ABSTRACT}

Potatoes are upland vegetable crops, which is the superior plant of Tosari District, Pasuruan Regency. Tosari potatoes are the largest contributor to production in East Java. The farmer profession is the main profession in this area, inherited from the family. The land area owned is inherited from the family. Agricultural land area varies, but still found farmers with a land area of more than one hectare. In this study, respondents were divided into two groups, namely farmers with a land area of $\geq 1$ hectare called cluster I and respondent farmers with a land area of $\leq 0.5$ hectares called cluster II. The purpose of this study was to analyze the effect of production inputs on potato production, to analyze the level of technical efficiency of potato farmers with different land areas, to analyze the factors affecting the level of technical efficiency. The study was conducted by interviewing 49 respondent farmers in Cluster I and 70 respondent farmers in Klaster II. This study uses the Cobb Douglas production function, the analytical methods used are the Stochastic Analysis Frontier (SFA) and the Tobit regression analysis. The results showed that the production inputs that had a significant effect on production in cluster I were seeds, fertilizers and manure, while in cluster II were fertilizers and pesticides. The level of technical efficiency of farmers who have a land area of $\geq 1$ hectare is greater than farmers with a land area of $\leq 0.5$ hectares. The land area has a significant effect on the level of technical efficiency.

\section{Riwayat Artikel}

Dikirim : 5 Mei, 2021

Disetujui : 15 September, 2021

Diterbitkan : 28 September, 2021

Kata Kunci

Efisiensi Teknis; Kentang;

Luas Lahan; Pasuruan

\section{ABSTRAK}

Kentang adalah tanaman sayuran dataran tinggi, yang menjadi tanaman unggulan Kecamatan Tosari Kabupaten Pasuruan. Kentang Tosari menjadi penyumbang produksi terbesar provinsi Jawa Timur. Profesi petani adalah profesi utama di daerah ini, yang didapat secara turun-temurun dari keluarga. Luas lahan yang diusahakan adalah warisan dari keluarga. Luas lahan pertanian bervariasi, namun masih ditemukan petani dengan luas lahan di atas satu hektar. Dalam penelitian ini responden dibedakan menjadi dua kelompok yaitu petani dengan luas lahan $\geq 1$ hektar disebut klaster I dan petani responden dengan luas lahan $\leq 0,5$ hektar disebut klaster II. Tujuan penelitian ini adalah menganalisis pengaruh input produksi terhadap produksi kentang, menganalisis tingkat efisiensi teknis petani kentang dengan luas lahan yang berbeda, menganalisis faktor-faktor yang mempengaruhi tingkat efisiensi teknis. Penelitian dilakukan dengan wawancara dari 49 petani responden di klaster I dan 70 petani responden di klaster II. Penelitian ini menggunakan fungsi produksi Cobb Douglas, metode analisis yang digunakan adalah Stochastic Analysis Frontier (SFA) dan analisis regresi Tobit. Hasil penelitian menyebutkan bahwa input produksi yang berpengaruh signifikan terhadap produksi di klaster I adalah benih, pupuk dan pupuk kandang sedangkan di klaster II adalah pupuk dan pestisida. Tingkat efisiensi teknis petani yang memiliki luas lahan $\geq 1$ hektar lebih besar daripada petani dengan luas lahan $\leq 0,5$ hektar. Luas lahan mempengaruhi secara signifikan terhadap tingkat efisiensi teknis.

Sitasi: Utami, D. C., \& Mamilianti, W. (2021). Efisiensi teknis usahatani kentang pada luas lahan yang berbeda di kabupaten Pasuruan. Agromix, 12(2), 33-42. https://doi.org/10.35891/agx.v12i2.2577

\section{PENDAHULUAN}

Indonesia saat ini telah swasembada kentang dengan daerah sentra kentang yang tersebar di beberapa provinsi, salah satunya adalah provinsi Jawa Timur. Sentra produksi kentang Jawa Timur adalah Magetan, Malang, Batu, Pasuruan, Probolinggo dan Lumajang. Sentra terbesar adalah Kabupaten Pasuruan dengan luas lahan 5.228 ha dan produksi 145.403 ton. Posisi ini menyumbang hampir 63,77\% dari produksi Jawa Timur (BPS Pasuruan, 2017). Produktivitas kentang Kabupaten Pasuruan pada tahun 2016 mencapai 27,8 ton/ha (BPS Pasuruan 2017). Kentang 
membutuhkan syarat tumbuh yang spesifik dan Kabupaten Pasuruan memiliki wilayah yang sesuai dengan syarat tumbuh kentang yaitu di sekitar lereng gunung Bromo.

Kentang adalah komoditi unggulan petani sayuran dataran tinggi, karena harga lebih stabil dan cukup bersaing dari pada tanaman sayuran lainnya. Pemasaran kentang yang semakin luas baik di dalam negeri dan luar negeri menjadikan usahatani kentang memiliki prospek yang cukup baik. Kentang memiliki daya simpan cukup lama atau tidak mudah rusak (Hartati \& Setyadji, 2012). Industri olahan pangan berbasis kentang semakin berkembang menjadikan permintaan kentang terus meningkat. Peningkatan permintaan kentang harus diimbangi dengan peningkatan produksi agar harga pasar tetap stabil. Perkembangan produksi dan produktivitas kentang di Indonesia dari tahun ke tahun masih mengalami fluktuasi.

Produktivitas suatu komoditi berkaitan erat dengan tingkat efisiensi teknis usahatani. Tingkat efisiensi teknis mempengaruhi tingkat produktivitas suatu komoditi. Upaya untuk meningkatkan produksi yaitu dengan penggunaan input yang optimal. Tingkat efisiensi teknis membantu mengetahui penggunaan input tersebut secara berlebihan atau sudah digunakan secara optimal atau kurang dimanfaatkan. Alokasi input yang berlebihan dapat meningkatkan biaya produksi, jika digunakan kurang dari dosis yang dianjurkan akan menurunkan produksi sehingga kemungkinan menghasilkan pengembalian yang rendah dari produksi kentang. Kumbhakar dan Lovell (2002) menjelaskan bahwa alokasi input produksi di tingkat petani berpengaruh terhadap jumlah produksi, produktivitas, dan menentukan tingkat efisiensi usaha yang dapat dicapai.

Alokasi penggunaan input dapat diukur dengan efisiensi teknis. Salah satu metode pengukuran efisiensi teknis yang digunakan adalah melalui pendekatan fungsi produksi stokasitik frontier. Coelli (1995) menjelaskan bahwa fungsi produksi frontier adalah pengembangan model deterministik yang mengukur efek tak terduga (stokastik frontier) dalam batas produksi. Penelitian yang membahas efisiensi teknis pertanian kentang telah dilakukan (Gebru dkk., 2017; Aheisibwe dkk., 2018; Andriatmoko dkk., 2018).

Petani kentang di Kabupaten Pasuruan adalah petani turun-temurun, di mana sistem budidaya dan penguasaan lahan adalah warisan dari orang tuanya. Kondisi ini berpengaruh pada penguasaan lahan yang dimiliki petani. Ratarata penguasaan lahan petani kentang di Pasuruan bervariasi, rentang penguasaan lahan yaitu 0,2 sampai lebih dari 1 hektar. Petani-petani yang memiliki lahan di atas 1 hektar adalah petani besar yang memiliki modal yang cukup. Penguasaan lahan selain berpengaruh pada kesejahteraan rumah tangga petani juga berpengaruh pada alokasi input dan total produksi yang diperoleh. Petani yang memiliki lahan luas tentunya membutuhkan alokasi input lebih besar dari pada petani yang memiliki lahan sempit. Permasalahannya adalah (1) bagaimana input produksi yang digunakan berpengaruh terhadap produk, (2) apakah petani dengan lahan yang lebih luas lebih efisien dalam alokasi input, (3) faktor-faktor apa sajakah yang menentukan efisiensi teknis usahatani kentang. Oleh karena itu penelitian ini dilakukan bertujuan untuk (1) menganalisis pengaruh input produksi terhadap produksi yang dihasilkan, (2) menganalisis tingkat efisiensi teknis petani kentang dengan luas lahan yang berbeda, (3) menganalisa faktor-faktor yang mempengaruhi tingkat efisiensi teknis. Diharapkan hasil penelitian ini memberikan informasi penting tentang tingkat efisiensi teknis petani kentang dengan penguasaan lahan yang berbeda.

\section{METODE}

Penelitian dilakukan di Kabupaten Pasuruan Kecamatan Tosari, berdasarkan pertimbangan bahwa Kecamatan Tosari adalah kecamatan di Kabupaten Pasuruan yang menyumbang produksi kentang dan luas lahan tertinggi (BPS Kabupaten Pasuruan, 2017). Penelitian dilakukan pada bulan September 2018.

Data yang digunakan dalam penelitian ini adalah data primer dari wawancara dengan petani. Data produksi yang diambil adalah data produksi bulan April-Juli 2018. Sampel adalah petani kentang di lokasi penelitian. Teknik pengambilan sampel menggunakan teknik multi-stage cluster sampling dengan lima tahap, yaitu: (1) menentukan kabupaten pusat kentang; (2) menentukan kecamatan pusat kentang di kabupaten terpilih; (3) menentukan desa sebagai lokasi penelitian, (4) menetapkan kelompok petani berdasarkan luas lahan yaitu kluster I petani dengan luas lahan $\geq 1$ hektar, kluster II petani dengan luas lahan $\leq$ 0,5 hektar; (5) menentukan jumlah sampel yaitu 50\% dari jumlah petani di kluster tersebut. Menurut Arikunto (2002), jika populasi lebih dari 100, sampel dapat diambil antara $10 \%$ - 15\% atau 20\% - 25\% atau lebih dari populasi. Dalam penelitian ini desa yang dipilih adalah desa Wonokitri, Mororejo, Tosari dan Baledono. Jumlah petani kluster I adalah 97 petani dan kluster II adalah 124 petani. Jumlah sampel adalah $50 \%$ dari jumlah petani di tiap-tiap kluster. Jumlah sampel untuk kluster I adalah 49 petani dan kluster Il sebesar 62 petani.

\section{Metode analisis faktor produksi}

Fungsi produksi yang digunakan adalah Fungsi Produksi Cobb Dauglas menggunakan pendekatan Stochastic Production Frontier. Model fungsi produksi tersebut dapat ditulis sebagai berikut :

$$
Y=\beta_{0} X_{1}^{\beta 1} X_{2}{ }^{\beta 2} X_{3}{ }^{\beta 3} X_{4}{ }^{\beta 4} X_{5}{ }^{\beta 5} e^{v i-u i}
$$


Persamaan ini dibuat dalam bentuk linier yaitu dengan menjadikannya dalam bentuk log natural agar terhindar dari heteroskedastisitas dan koefisien regresi dapat dibaca sebagai elastisitas produksi (Novia dkk., 2020). Persamaan tersebut yaitu:

$$
\ln P r o d=\beta_{0}+\beta_{1} \ln B n h_{i}+\beta_{2} \ln P p k_{i}+\beta_{3} \ln K D G_{i}+\beta_{4} \ln P e s_{i}+\beta_{5} \ln T K_{i}+V_{i}-U_{i}
$$

Keterangan:

$\begin{array}{ll}\text { Bnh } & \text { : jumlah benih } \\ \text { Ppk } & \text { : jumlah pupuk anorganik } \\ \text { KDG } & \text { : jumlah pupuk kendang } \\ \text { Pes } & \text { : Jumlah Pestisida } \\ \text { TK } & \text { : jumlah Tenaga Kerja } \\ \text { i } & \text { : Jumlah petani responden } \\ \beta_{0} & \text { : Intersep }\end{array}$

- Intersep

$\beta_{1}-\beta_{6}:$ koefisien parameter dugaan variabel/faktor produksi $\left(\beta_{1}-\beta_{6}>0\right)$

$\mathrm{V}_{\mathrm{i}}-\mathrm{U}_{\mathrm{i}} \quad$ : Error (efek inefisiensi dalam model)

$\mathrm{V}_{\mathrm{i}} \quad$ : Variabel acak, di mana variabel tersebut merupakan faktor eksternal (Iklim, serangan hama penyakit atau kesalahan dalam permodelan) sebarannya simetris dan menyebar normal $\left(V_{i j} \sim N\left(0, \sigma v^{2}\right)\right.$

$\mathrm{U}_{\mathrm{i}} \quad$ : Variabel acak bernilai positif (variabel tersebut diasumsikan memiliki pengaruh terhadap inefisiensi teknis serta hubungan dengan faktor internal). Variabel tersebut juga memiliki sebaran setengah normal

$$
\left(V_{i j} \sim \mid N\left(0, \sigma v^{2} \mid\right)\right.
$$

\section{Metode analisis pengukuran efisiensi teknis}

Pengukuran efisiensi teknis menggunakan formula sebagai berikut (Coelli, dkk. 2005) :

$$
T E=\frac{y_{i}}{y_{i}^{*}}=\frac{\exp \left(x_{i} \beta+v_{i}-u_{i}\right)}{\exp \left(x_{i} \beta+v_{i}\right)}=\exp \left(-u_{i}\right)
$$

Dimana $\boldsymbol{y}_{\boldsymbol{i}}$ adalah produksi aktual dari pengamatan, $\boldsymbol{y}_{\boldsymbol{i}}^{*}$ adalah dugaan produksi potensial dari fungsi frontier stokastik. Efisiensi teknis untuk seorang petani berkisar 0 dan 1 . Efisiensi teknis tersebut memiliki nilai yang berkebalikan dengan efek inefisiensi teknis.

\section{Metode analisis faktor-faktor yang mempengaruhi efisiensi teknis}

Dalam mengestimasi faktor-faktor yang mempengaruhi tingkat efisiensi teknis digunakan model regresi tobit. Penelitian ini menggunakan regresi tobit karena nilai dari variabel tidak bebas yaitu indeks efisiensi teknis di batasi (consered) antara 0 - 1. Model untuk menghitung TE (Techincal Efficiency) masing-masing dianalisis secara terpisah. Dalam menaksir parameter regresi tobit digunakan MLE (Maximum Likelihood Estimator). Model estimasi faktor yang berpengaruh terhadap tingkat efisiensi menggunakan model regresi tobit yaitu :

Keterangan:

$$
T E=\partial_{0}+\partial_{1} Z_{1}+\partial_{2} Z_{2}+\partial_{3} Z_{3}+\partial_{4} Z_{4}+\partial_{5} Z_{5}+\partial_{6} D_{1}+\varepsilon
$$

$\mathrm{Z}_{1} \quad$ : Luas lahan (hektar)

$Z_{2}$ : Umur petani (tahun)

$Z_{3}$ : Tingkat pendidikan petani (tahun)

$\mathrm{Z}_{4} \quad$ : Pengalaman berusaha tani (tahun)

$Z_{5} \quad$ : Jumlah anggota keluarga (orang)

$\mathrm{D}_{1} \quad$ : Pekerjaan di luar pertanian, bernilai 1 jika melakukan pekerjaan di luar pertanian, bernilai 0 jika tidak melakukan.

$\varepsilon \quad$ : random error term yang diasumsikan bebas dan didistribusikan bebas dan distribusinya terpotong normal dengan $\mathrm{N}(0, \delta)$

$\vartheta \quad$ : Koefisien parameter variabel yang diestimasi

\section{HASIL DAN PEMBAHASAN}

\section{Karakteristik petani responden}

Karakteristik petani tidak lepas dari faktor-faktor yang terkait dengan kondisi petani dari aspek sosial, ekonomi, budaya dan aspek manajemen. Pada penelitian ini karakteristik petani dilihat dari aspek sosial dan ekonomi. Aspek sosial ekonomi petani yang dianalisis adalah umur, pendidikan, pengalaman usahatani, jumlah anggota keluarga, luas lahan dan pekerjaan di luar pertanian. Petani responden sesuai tujuan penelitian maka dibedakan menjadi dua kelompok yaitu petani responden yang memiliki luas $\geq 1$ hektar disebut klaster I dan petani responden yang memiliki luas lahan $\leq$ 0,5 hektar disebut klaster II. Rata-rata karakteristik petani responden dapat dilihat pada tabel 1. 
Petani kentang di lokasi penelitian adalah sebagian besar petani yang meneruskan usaha dari keluarga atau orang tuanya. Lahan yang diusahakan sebagian besar adalah milik sendiri. Status lahan milik sendiri memberikan keleluasaan petani untuk mengelola lahan dengan baik tanpa terikat oleh pihak lain. Luas lahan yang diusahakan petani untuk budidaya sangat erat hubungannya dengan penggunaan input produksi seperti benih, pupuk, obat, tenaga kerja, air. Lahan yang semakin luas maka kebutuhan input produksi akan lebih besar daripada lahan yang lebih kecil, di mana hal ini menentukan modal yang harus disediakan. Luas lahan yang lebih luas dengan input yang lebih besar tentunya menghasilkan produksi yang lebih besar. Rata-rata luas lahan petani responden pada klaster I adalah 1,591 hektar dana pada klaster II adalah 0,381 hektar.

Tabel 1. Karakteristik petani responden pada kluster I dan klaster II tahun 2018

\begin{tabular}{llccc}
\hline \multirow{2}{*}{ No } & \multirow{2}{*}{ Variabel } & \multicolumn{2}{c}{ Rata-Rata } & \multirow{2}{*}{ Satuan } \\
\cline { 3 - 4 } & & Klaster I $(\geq 1$ ha) & Klaster II $(\leq 0.5$ ha $)$ & \\
\hline 1. & Luas lahan & 1,591 & 0,381 & hektar \\
2. & Umur petani & 42,347 & 43,2 & tahun \\
3. & Pendidikan petani & 8,897 & 9,17 & tahun \\
4. & Pengalaman usahatani & 31,816 & 30,5 & Tahun \\
5. & Jumlah anggota keluarga & 4,347 & 4,25 & orang \\
\hline
\end{tabular}

Sumber: data diolah tahun 2018

Umur petani menjadi variabel pengamatan karena umur dapat mempengaruhi produktivitas petani dalam mengelola usahataninya. Petani dengan umur lebih tua secara fisik telah menurun produktivitas dan menyebabkan pengelolaan usahatani kurang optimal. Petani muda lebih aktif dan intensif dalam mengelola usaha karena fisik yang lebih kuat dan memiliki produktivitas lebih tinggi daripada petani tua. Rata-rata umur petani dalam penelitian ini adalah 42,347 tahun di klaster I dan 43,2 di klaster II. Secara umum umur petani di lokasi penelitian rata-rata antara usia 40-45 tahun.

Pengamatan tingkat pendidikan dilakukan untuk melihat sebaran tingkat pendidikan petani responden. Tingkat pendidikan menjadi indikator kualitas sumberdaya manusia khususnya dalam difusi dan adopsi teknologi pertanian. Petani dengan tingkat pendidikan lebih tinggi maka pada umumnya kemampuan penerapan dan manajemen pengelolaan usahatani lebih baik. Petani lebih kreatif dan inovatis dalam mengelola usahatani sehingga lebih efisien. Pendidikan dianggap sebagai investasi di mana pendidikan yang lebih tinggi mampu meningkatkan pengetahuan, keterampilan dan keahlian petani sebagai modal untuk bekerja lebih produktif sehingga dapat meningkatkan kemampuan manajerial dan penghasilannya di masa yang akan datang. Rata-rata tingkat Pendidikan petani responden adalah 8,897 tahun di klaster I dan 9,17 di klaster II, dengan kata lain secara umum tingkat Pendidikan petani responden adalah Sekolah Menengah Pertama (SMP).

Pengalaman petani dalam berusahatani berkaitan erat dalam mengelola usahatani. Petani yang telah lama dalam mengelola atau berperan dalam usahatani memiliki kemampuan yang lebih luas dalam bercocok tanam dan pengambilan keputusan dalam menghadapi kendala dan peluang usaha. Profesi sebagai petani bagi masyarakat di lokasi penelitian adalah profesi yang telah ditekuni secara turun-temurun dan komoditi yang diusahakan adalah tanaman sayuran dataran tinggi yang sesuai dengan lingkungannya. Pengalaman usahatani telah diperoleh dari keluarga yaitu kakek, paman dan atau orang tua. Mereka sejak usia anak-anak telah dilibatkan dalam kegiatan pertanian. Pengalaman usahatani di sini diukur seberapa lama petani telah melakukan usahatani kentang baik itu sebagai petani pemilik atau sebagai tenaga kerja keluarga. Rata-rata pengalaman berusaha tani petani responden adalah 31,816 tahun di klaster I dan 30,5 tahun di klaster II.

Jumlah anggota keluarga petani responden yang dimaksud adalah istri, anak dan orang lain yang tinggal dalam satu rumah ataupun yang tinggal di luar rumah namun biaya hidup masih menjadi tanggungan kepala keluarga. Jumlah anggota keluarga menjadi pengamatan dalam penelitian ini karena petani dalam berusaha tani sering kali menggunakan anggota keluarga menjadi tenaga kerja yang membantu dalam berusaha tani, selain itu menjadi motivasi petani untuk lebih giat dalam bekerja karena semakin banyak jumlah anggota keluarga yang menjadi tanggungannya maka semakin besar kebutuhan keluarga yang harus dicukupi oleh petani. Rata-rata jumlah anggota keluarga petani di lokasi penelitian adalah 4,347 orang diklaster I dan 4,25 di klaster II, secara umum jumlah anggota keluarga petani adalah 4 orang.

Petani di kedua klaster tidak semua memiliki profesi di luar pertanian, artinya petani ada yang bekerja di luar pertanian dan ada yang tidak. Alasan utama mereka memiliki pekerjaan ganda adalah untuk mencari pendapatan tambahan untuk mencukupi kebutuhan keluarga. Pekerjaan di luar pertanian yang dilakukan petani responden adalah pedagang, pemandu wisata, perangkat desa dan pekerja seni. Petani klaster I yang memiliki pekerjaan di luar pertanian sejumlah 22 orang atau sebesar 44,89\% dari jumlah responden dan di klaster II sebanyak 30 orang atau $42,85 \%$ dari jumlah petani responden. 


\section{Faktor produksi yang mempengaruhi produksi kentang}

Analisis pengaruh faktor produksi terhadap produksi kentang menggunakan fungsi produksi Cobb Douglas Stochastic Frontier. Hasil estimasi pengaruh faktor input terhadap produksi kentang di kedua lokasi penelitian bisa dilihat di tabel 2 dan tabel 3.

\section{Klaster I ( $\geq 1$ ha)}

Tabel 2. Menunjukkan bahwa faktor produksi yang mempengaruhi produksi kentang secara nyata adalah benih, pupuk anorganik dan pupuk kendang, sedangkan pestisida dan tenaga kerja tidak berpengaruh nyata. Pada tabel tersebut memperlihatkan bahwa nilai sigma square 0,0251 dan nilai gamma 0,8714, kedua nilai ini lebih besar dari nol sehingga asumsi distribusi setengah normal diterima.

Penggunaan benih berpengaruh nyata positif terhadap produksi kentang pada taraf kepercayaan 99\%. Ini artinya bahwa penambahan penggunaan bibit kentang dapat meningkatkan produksi kentang. Temuan ini sama dengan beberapa hasil penelitian lain tentang efisiensi teknis usahatani kentang yang menyatakan bahwa benih berpengaruh nyata positif terhadap produksi kentang (Nurhapsa, 2013; Riskiyah dkk., 2014). Rata-rata petani kentang di lokasi penelitian klaster I mampu menyediakan benih dengan kualitas baik, telah tersertifikasi yang diperoleh dari penyedia bibit kentang. Varietas benih yang digunakan adalah granula kembang. Pupuk berpengaruh nyata positif terhadap produksi kentang dengan nilai elastisitas yang tinggi yaitu sebesar 0,3348 . Ini artinya jika penggunaan pupuk anorganik ditambah $1 \%$ maka produksi kentang akan meningkat sebesar 0,3348\%. Penggunaan pupuk dalam budidaya kentang sangat diperlukan. Tanaman kentang menghendaki tanah yang subur untuk pembentukan umbi. Petani masih menggunakan pupuk di bawah dosis yang dianjurkan sehingga masih perlu ditingkatkan. Novia dkk. (2020) menyatakan bahwa penggunaan pupuk berpengaruh nyata positif terhadap produksi. Pupuk kandang berpengaruh nyata positif terhadap produksi kentang pada taraf kepercayaan 99\% dengan nilai elastisitas produksi sebesar 0,5041. Ini artinya bahwa penggunaan pupuk kendang ditambah $1 \%$ maka produksi kentang akan meningkat sebesar 0,5041\%. Pupuk kendang memiliki peran sangat penting dalam pertumbuhan tanaman kentang. Pembentukan umbi kentang membutuhkan tanah yang subur dan gembur. Peran pupuk kendang selain menambah nutrisi tanah juga memperbaiki struktur fisik tanah.

Faktor produksi pestisida dan tenaga kerja di klaster ini menunjukkan tidak berpengaruh nyata terhadap produksi kentang. Penggunaan pestisida di klaster ini melebihi dosis anjuran yang diberikan oleh PPL setempat. Hal ini disebabkan oleh musim hujan yang terjadi pada masa tanam pengamatan. Petani cenderung menambah frekuensi penyemprotan. Petani memiliki persepsi bahwa serangan penyakit tanaman pada musim hujan semakin tinggi.

Tabel 2. Hasil estimasi fungsi produksi cobb douglas stochastik frontier pada klaster I ( $\geq 1$ ha)

\begin{tabular}{|c|c|c|c|c|}
\hline \multirow[t]{2}{*}{ Variabel } & \multicolumn{4}{|c|}{ MLE (Maximum Likelihood Estimate) } \\
\hline & Parameter & Koefisien & Standar Error & t- hitung \\
\hline Konstanta & $\beta_{0}$ & 5,4931 & 0,5615 & $9,7818 * * *$ \\
\hline X1 Benih & $\beta_{1}$ & 0,1996 & 0,0793 & $2,5168 * * *$ \\
\hline X2 Pupuk & $\beta_{2}$ & 0,3348 & 0,0821 & $4,0812 * * *$ \\
\hline X3 Pupuk Kandang & $\beta_{3}$ & 0,5041 & 0,1429 & $3,5258 * * *$ \\
\hline X4 Pestisida & $\beta_{4}$ & $-2,2028$ & 0,2233 & $-0,9083^{\text {ns }}$ \\
\hline X5 tenaga Kerja & $\beta_{5}$ & 0,0259 & 0,0328 & $0,7652^{\text {ns }}$ \\
\hline Sigma Square & $\sigma^{2}$ & 0,0251 & 0,0095 & $2,6262 * * *$ \\
\hline Gamma & $\gamma$ & 0,8714 & 0,1572 & $5,5422 * * *$ \\
\hline \multicolumn{5}{|l|}{ Log Likelihood Function : 42,1025 } \\
\hline \multicolumn{5}{|l|}{$L R$ test $: 2,0645$} \\
\hline $\begin{aligned} \text { Keterangan : } & * * * \text { signifikan pada } \alpha=0,01 \\
& * * \text { signifikan pada } \alpha=0,05 \\
& * \text { signifikan pada } \alpha=0,1 \\
& \text { ns tidak signifikan }\end{aligned}$ & & & & \\
\hline
\end{tabular}

Sumber: data diolah tahun 2018

\section{Klaster II ( $\leq$ 0.5ha)}

Pada klaster ini faktor produksi yang mempengaruhi produksi kentang secara nyata adalah pupuk anorganik dan pestisida, sedangkan benih, pupuk kendang dan tenaga kerja tidak berpengaruh nyata. Tabel 3 juga memperlihatkan bahwa nilai sigma square 0,0823 dan nilai gamma 0,9679, kedua nilai ini lebih besar dari nol sehingga asumsi distribusi setengah normal diterima. 
Tabel 3. Hasil estimasi fungsi produksi cobb douglas stochastik frontier pada kluster II $(\leq 0,5 \mathrm{ha})$

\begin{tabular}{lcccc}
\hline Variabel & \multicolumn{4}{c}{ MLE (Maximum Likelihood Estimate) } \\
\cline { 2 - 5 } & Parameter & Koefisien & Standart Error & $\mathrm{t}$ - hitung \\
\hline Konstanta & $\beta_{0}$ & 1,7191 & 0,7091 & $2,4241^{* * *}$ \\
X1 Benih & $\beta_{1}$ & 0,1407 & 0,0936 & $1,5023^{\text {ns }}$ \\
X2 Pupuk & $\beta_{2}$ & 0,6027 & 0,0865 & $6,9661^{* * *}$ \\
X3 Pupuk Kandang & $\beta_{3}$ & $-0,00611$ & 0,1334 & $-0,0458^{\text {ns }}$ \\
X4 Pestisida & $\beta_{4}$ & 0,4241 & 0,1125 & $3,7684^{* * *}$ \\
X5 Tenaga Kerja & $\beta_{5}$ & 0,0215 & 0,0411 & $0,5227^{\text {ns }}$ \\
Sigma Square & $\sigma^{2}$ & 0,0823 & 0,0211 & $3,9089^{* * *}$ \\
Gamma & $\gamma$ & 0,9679 & 0,0455 & $21,2668^{* * *}$ \\
\hline
\end{tabular}

Log Likelihood Function $=27,5547$

\begin{aligned} \hline LR test $=9,6839 & \\$\hline Keterangan : & $* * *$ signifikan pada $\alpha=0,01 \\ & * *$ signifikan pada $\alpha=0,05 \\ & *$ signifikan pada $\alpha=0,1 \\ &$ ns tidak signifikan \end{aligned}

Sumber: data diolah tahun 2018

Faktor produksi yang mempengaruhi produksi kentang secara nyata adalah pupuk dan pestisida. Rata-rata penggunaan pupuk petani di klaster ini $500.71 \mathrm{~kg} / \mathrm{ha}$. Rata-rata penggunaan pupuk ini masih perlu ditingkatkan karena masih di bawah dosis anjuran yaitu $800 \mathrm{~kg} / \mathrm{ha}$. Nilai elastisitas pupuk adalah 0,6027 dan nyata pada taraf kepercayaan 99\%, ini artinya bahwa jika pupuk jumlah penggunaannya ditingkatkan 1\% maka produksi kentang akan meningkat sebesar 0,6027\%. Hasil temuan ini sesuai dengan penelitian yang dilakukan oleh Maganga (2012) yang menyatakan bahwa penggunaan pupuk berpengaruh nyata positif pada produksi kentang. Penggunaan pestisida pada klaster ini memperlihatkan bahwa pestisida berpengaruh nyata pada taraf kepercayaan 99\% dengan nilai elastisitas 0,4241. Ini artinya bahwa penggunaan pestisida masih perlu ditingkatkan. Penggunaan pestisida di tingkat petani lebih variasi dibandingkan dengan petani di klaster I. Pengetahuan petani di klaster II tentang pestisida yang tepat lebih baik, hal ini dikarenakan petani di klaster ini memiliki modal yang terbatas sehingga lebih selektif dalam memilih input produksi.

\section{Tingkat efisiensi teknis usahatani kentang}

Total produksi pada setiap petani dalam usahatani sering kali menunjukkan perbedaan. Perbedaan jumlah produksi yang dicapai oleh petani disebabkan oleh perbedaan input yang digunakan dan kemampuan petani dalam mengelola usahataninya. Analisis efisiensi teknis ini dimaksudkan untuk mengetahui tingkat efisiensi teknis petani kentang di kedua daerah penelitian, di mana efisiensi teknis berhubungan dengan alokasi input produksi. Sebaran tingkat efisiensi teknis di kedua lokasi penelitian dapat dilihat pada tabel 4, gambar 1 dan gambar 2.

Table 4. Distribusi tingkat efisiensi teknis

\begin{tabular}{lcccc}
\hline \multirow{2}{*}{ Range Efisiensi Teknis } & \multicolumn{2}{c}{ klaster I ( $\geq 1$ ha) } & \multicolumn{2}{c}{ kKlaster II $(\leq 0.5 \mathrm{ha})$} \\
\cline { 2 - 5 } & Frekuensi & Persentase (\%) & Frekuensi & Persentase \\
\hline $0.0-0.5$ & 0 & 0 & 0 & 0 \\
$0.51-0.6$ & 0 & 0 & 5 & 7,14 \\
$0.61-0.7$ & 0 & 0 & 9 & 12,86 \\
$0.71-0.8$ & 5 & 10,21 & 17 & 24,29 \\
$0.81-0.9$ & 18 & 36,73 & 20 & 28,57 \\
$0.91-1.0$ & 26 & 53,06 & 19 & 27,14 \\
Total & 49 & 100 & 70 & 100 \\
\hline Minimum Technical Efficiency & \multicolumn{3}{c}{0,744} & 0,974 \\
\hline Maximum Technical Efficiency & 0,975 & 0,807 \\
\hline Average Technical Efficiency & \multicolumn{3}{c}{0,891} \\
\hline
\end{tabular}

Sumber: data diolah tahun 2018

Rata-rata tingkat efisiensi teknis di klaster I adalah 0,891 dan 0,807 di klaster II, ini artinya bahwa petani di klaster I masih dapat meningkatkan total produksi sebesar 10,9\% sedangkan di klaster II masih bisa meningkatkan produksi sebesar 19,3\%. Dari hasil ini dapat dilihat bahwa tingkat efisiensi teknis pada petani yang lahan garapannya lebih luas lebih tinggi tingkat efisiensi teknisnya. Petani di klaster II tingkat efisiensi teknis terendah adalah 0,501 sedangkan di klaster I adalah 0,744. Efisiensi tertinggi di klaster I adalah 0,891 sedangkan di klaster II adalah 0,974. Dari perbandingan hasil estimasi ini dapat dilihat bahwa petani di kedua lokasi penelitian masih perlu meningkatkan total produksinya. Sebaran tingkat efisiensi teknis tiap petani dapat dilihat pada gambar 1 dan 2 berikut ini. 


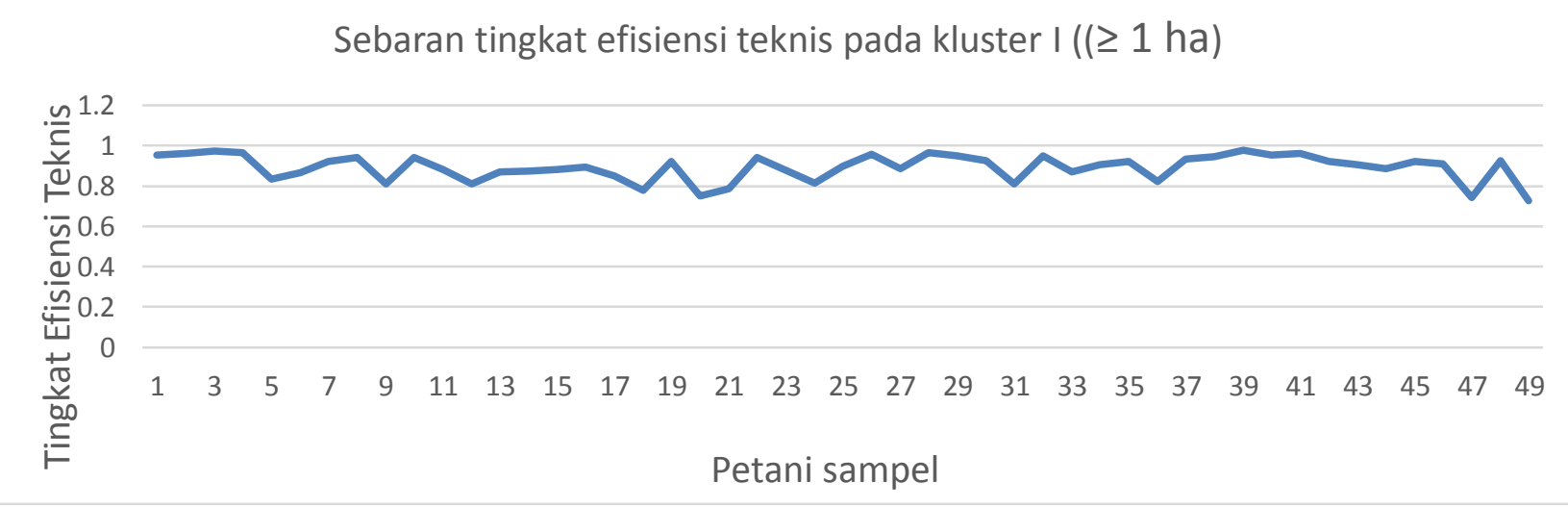

Gambar 1. Sebaran tingkat efisiensi teknis pada setiap petani di klaster I

Sebaran tingkat efisiensi teknis pada kluster II (( $\leq 0.5 \mathrm{ha})$

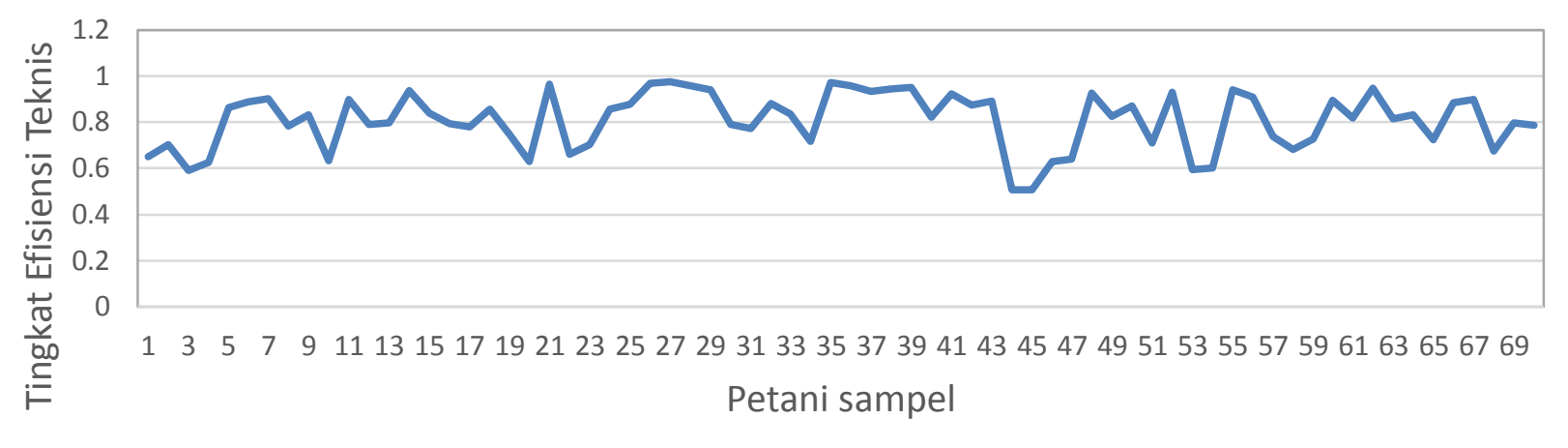

Gambar 2. Sebaran tingkat efisiensi teknis pada setiap petani di klaster I

\section{Faktor-faktor yang mempengaruhi tingkat efisiensi teknis}

Uji statistik Likelihood Ration Test digunakan untuk mengetahui apakah parameter yang digunakan secara simultan berpengaruh signifikan terhadap model. Pada tabel 5 klaster I menunjukkan bahwa nilai uji Likelihood Ratio sebesar 74,36181 dengan probabilitas 0,0000 sedangkan di tabel 6 pada klaster II nilai LR adalah 58,18618 dengan probabilitas 0,0000 . Ini artinya bahwa secara Bersama variable independent $(X)$ dalam model dapat mempresentasikan nilai $Y$ yaitu efisiensi teknis,

Tabel 5. Hasil analisis faktor-faktor yang mempengaruhi tingkat efisiensi teknis pada kluster I ( $\geq 1$ ha)

\begin{tabular}{lllll}
\hline Variabel & Koefisien & Standar Error & Statistik-t & Probabilitas \\
\hline$X_{1}$ & $0,000003^{* *}$ & 0,000001 & 2,039017 & 0,0414 \\
$X_{2}$ & $0,000086^{\text {ns }}$ & 0,001781 & 0,048778 & 0,9611 \\
$X_{3}$ & $-0,000419$ & 0,001375 & $-0,304908$ & 0,7604 \\
$X_{4}$ & $-0,005310^{* * *}$ & 0,001947 & $-2,727157$ & 0,0064 \\
$X_{5}$ & $-0,012019^{\text {ns }}$ & 0,007499 & $-1,602765$ & 0,1090 \\
$D_{1}$ & $0,029404^{* *}$ & 0,016060 & 1,830847 & 0,0671 \\
Konstanta & $0,934455^{* * *}$ & 0,070921 & 13,17594 & 0,0000 \\
\hline
\end{tabular}

\begin{tabular}{l}
\hline $\mathrm{LRChi}^{2}=118,23$ Prob $>\mathrm{chi}^{2}=0,0000$ \\
\hline Keterangan : $\mathrm{X}_{1}=$ luas lahan $; \mathrm{X}_{2}=$ umur petani; $\mathrm{X}_{3}=$ pendidikan petani \\
$\mathrm{X}_{4}=$ pengalaman Usahatani; $\mathrm{X}_{5}=$ Jumlah Tanggungan Keluarga \\
$\mathrm{D}_{1}=$ Dummy pekerjaan di luar pertanian, bernilai 1 jika melakukan dan 0 jika tidak. \\
$* * *$ signifikan pada $\alpha=0,01$ \\
$* *$ signifikan pada $\alpha=0,05$ \\
$*$ signifikan pada $\alpha=0,1$ \\
ns tidak signifikan
\end{tabular}

Sumber: data primer diolah tahun 2018

Pada tabel 5 menunjukkan bahwa faktor sosial ekonomi yang berpengaruh nyata terhadap tingkat efisiensi teknis adalah luas lahan, pengalaman usahatani dan pekerjaan diluar pertanian. Luas lahan dan pekerjaan di luar pertanian nyata positif pada taraf kepercayaan $95 \%$ sedangkan pengalaman berusahatani nyata positif pada taraf $99 \%$. Petani dengan luas lahan yang lebih luas memiliki potensi untuk meningkatkan tingkat efisiensinya. Pengalaman petani di klaster I rata-rata adalah 31,816 tahun, nilai ini membuktikan bahwa petani di klaster I telah cukup lama dalam 
berusahatani sehingga mampu mengelola usahataninya lebih efisien. Kemampuan mengelola usahatani dengan luas lahan yang luas tidak mudah sehingga dengan pengalaman yang dimiliki petani mampu mengambil keputusankeputusan yang tepat dalam menghadapi kendala dan kelemahan usahataninya. Petani di klaster I sebanyak 22 orang memiliki pekerjaan diluar usahatani. Sebagian besar mereka adalah pedagang besar untuk komoditi sayuran dataran tinggi termasuk kentang. Beberapa penelitian yang menyatakan bahwa pengalaman usahatani menunjukkan pengaruh nyata terhadap efisiensi teknis yaitu pada penelitian Maganga (2012). Lain halnya pada penelitian Maryanto dkk. (2018) menyatakan bahwa pengalaman usahatani tidak berpengaruh nyata terhadap tingkat efisiensi teknis hal ini disebabkan rata-rata pengalaman usahatani petani kentang di Sumatera Selatan adalah 2,03 tahun tergolong petani baru.

Tabel 6. Hasil analisis faktor-faktor yang mempengaruhi tingkat efisiensi teknis pada kluster II $(\leq 0,5 \mathrm{ha})$

\begin{tabular}{lllll}
\hline Variabel & Koefisien & Standart Error & Statistik-t & Probabilitas \\
\hline$X_{1}$ & $0,000002^{* *}$ & 0,000001 & 2,539381 & 0,0111 \\
$X_{2}$ & $-0,001340^{\text {ns }}$ & 0,004075 & $-0,328729$ & 0,7424 \\
$X_{3}$ & $0,011757^{* *}$ & 0,005824 & 2,018706 & 0,0435 \\
$X_{4}$ & $0,001774^{\text {ns }}$ & 0,002388 & 0,742872 & 0,4576 \\
$X_{5}$ & $-0,012271^{\text {ns }}$ & 0,015388 & $-0,797426$ & 0,4252 \\
$D_{1}$ & $0,083127^{* * *}$ & 0,026195 & 3,173352 & 0,0015 \\
Konstanta & $0,614605^{* * *}$ & 0,170235 & $3, .610329$ & 0,0003 \\
\hline
\end{tabular}

$\mathrm{LRChi}^{2}=58,18618$ Prob $>\mathrm{chi}^{2}=0,0000$

Keterangan : $X_{1}=$ luas lahan $; X_{2}=$ Umur petani; $X_{3}=$ Pendidikan Petani

$\mathrm{X}_{4}=$ Pengalaman Usahatani; $\mathrm{X}_{5}=$ Jumlah Tanggungan Keluarga

$\mathrm{D}_{1}=$ Dummy pekerjaan diluar pertanian, bernilai 1 jika melakukan dan 0 jika tidak.

$* * *$ signifikan pada $\alpha=0,01$

** signifikan pada $\alpha=0,05$

* signifikan pada $\alpha=0,1$

ns tidak signifikan

Sumber: data primer diolah tahun 2018

Pada tabel 6 menunjukkan bahwa pada klaster II, faktor sosial ekonomi yang berpengaruh nyata terhaap tingkat efisiensi teknis adalah luas lahan, tingkat Pendidikan petani dan pekerjaan di luar pertanian. Luas lahan dan tingkat pendidikan petani nyata positif pada taraf kepercayaan 95\% sedangkan pekerjaan diluar pertanian nyata positif pada taraf $99 \%$. Sama dengan petani di klaster I bahwa petani yang memiliki luas lahan yang lebih luas berpotensi mencapai tingkat efisiensi lebih tinggi. Petani di klaster II rata-rata berpendidikan SMP namun yang berpendidikan SMA lebih banyak daripada petani di klaster I, ini menyebabkan rata-rata petani di klaster II menempuh pendidikan lebih lama dibandingkan petani di klaster I. Tingkat pendidikan berpengaruh nyata positif terhadap tingkat efisiensi teknis. Petani yang berpendidikan tinggi cenderung memiliki motivasi yang lebih besar untuk kemajuan pertaniannya sehingga bisa mencapai tingkat efisiensi lebih tinggi. Petani dengan pendidikan lebih tinggi memungkinkan petani lebih inovatif dan berani menerakan teknologi yang bermanfaat untuk peningkatan produksi. Beberapa studi tentang efisiensi teknis pertanian menemukan bahwa tingkat pendidikan memiliki pengaruh positif yang signifikan terhadap efisiensi teknis (Baten dkk., 2014; Makombe dkk., 2016; Hong dkk., 2017; Adamie dkk., 2018; Ahaesibwe dkk., 2018). Pekerjaan di luar pertanian berpengaruh nyata pada tingkat efisiensi teknis. Ini berarti bahwa petani yang memiliki pekerjaan diluar pertanian baik yang berhubungan dengan usahatani ataupun tidak berpeluang untuk mencapai tingkat efisiensi teknis lebih tinggi. Petani di klaster II selain sebagai petani juga bekerja sebagai pedagang, pemandu wisata dan pekerja seni. Kepemilikan lahan yang sempit menyebabkan mereka berusaha mencari mata pencaharian lain untuk mencukupi kebutuhan keluarga, selain untuk tambahan modal dalam berusahatani.

\section{KESIMPULAN}

Hasil analisis fungsi produksi menyatakan bahwa faktor produksi yang berpengaruh nyata terhadap produksi di kedua klaster berbeda. Pada klaster I dengan kepemilikan lahan $\geq 1$ hektar faktor produksi yang berpengaruh nyata terhadap produksi adalah benih, pupuk dan pupuk kendang, sedangkan pestisida dan tenaga kerja tidak berpengaruh nyata. Pada klaster II dengan kepemilikan lahan $\leq 0,5$ hektar faktor produksi yang berpengaruh nyata adalah pupuk dan pestisida, sedangkan benih, pupuk kendang dan tenaga kerja tidak memberikan pengaruh nyata. Produksi kentang di kedua klaster masih bisa ditingkatkan mengingat hasil estimasi tingkat efisiensi teknis di kedua klaster kurang dari 1. Faktor produksi yang paling bisa dioptimalkan dalam peningkatan produksi di kedua klaster adalah pupuk anorganik. Rata-rata tingkat efisiensi teknis di klaster I adalah 0,891 dengan tingkat efisiensi terendah adalah 0,744 dan tertinggi 0,975. Rata-rata tingkat efisiensi teknis di klaster II adalah 0,807 dengan tingkat efisiensi terendah adalah 0,501 dan tertinggi 0,974. Faktor-faktor sosial ekonomi yang mempengaruhi secara nyata dalam peningkatan efisiensi teknis usahatani kentang di kedua lokasi penelitian adalah luas lahan dan pekerjaan di luar pertanian. Petani 
dengan luas lahan yang lebih besar menunjukkan tingkat efisiensi teknis lebih tinggi. Petani yang memiliki pekerjaan ganda yaitu bekerja sebagai petani dan bekerja di sektor non pertanian memiliki peluang untuk berusahatani lebih efisien. Petani di klaster I yang memiliki pengalaman berusahatani lebih lama berpeluang meningkatkan produksi, sedangkan petani di klaster II dengan tingkat pendidikan yang lebih tinggilah yang berpeluang meningkatkan produksi.

Penggunaan input pupuk anorganik perlu di perhatikan dosis dan waktu aplikasinya karena pupuk adalah input penting dalam budidaya kentang di daerah penelitian. Petani yang memiliki pekerjaan ganda perlu mengatur waktu sehingga pekerjaan di sektor pertanian tidak terabaikan. Petani perlu meningkatkan pengetahuan dan keterampilan dalam budidaya dengan mengikuti berbagai pelatihan yang berhubungan dengan pengelolaan usahatani kentang. Petani yang memiliki luas lahan kurang dari 0,5 hektar perlu dipikirkan untuk bergabung dengan sesama petani dengan luasan yang sama agar usahatani lebih efisien.

\section{DAFTAR PUSTAKA}

Adamie, B. A., Balezentis, T., \& Asmild, M. (2019). Environmental production factors and efficiency of smallholder agricultural households: using non-parametric conditional frontier methods. Journal of Agricultural Economics, 70(2), 471-487. https://doi.org/10.1111/1477-9552.12308

Aheisibwe, A.R., Lokina, R. B., dan Hepelwa, A. S. 2018. Technical Efficiency in Seed Potato Production Systems in Uganda. Journal of Economics and Behavioral Studies, 10(3), 122-140. https://doi.org/10.22610/jebs.v10i3.2322

Andriatmoko, N. D., Hanani, N., Syafrial, S., \& Ke-Chung, P. (2018). Analysis the impact factors of application conservation farming on productivity potato farming In Bumiaji Batu Indonesia. Agricultural Socio-Economics Journal, 18(1), 37-41. https://doi.org/10.21776/ub.agrise.2018.018.1.6

Arikunto, (2002). Prosedur suatu penelitian pendekatan praktek. Jakarta: Rineka Cipta

Badan Pusat Statistik Pasuruan. (2017). Kabupaten pasuruan dalam angka 2017. Badan Pusat Statistik Pasuruan.

Baten, A., \& Hossain, I. (2018). Stochastic frontier model with distributional assumptions for rice production technical efficiency. Journal Of Agricultural Science And Technology (JAST),16(3), 481-496.

Coelli, T. J. (1995). Recent developments in frontier modelling and efficiency measurement. Australian Journal of agricultural economics, 39(3), 219-245. https://doi.org/10.1111/j.1467-8489.1995.tb00552.x

Coelli. (2005). An Introduction to efficiency and productivity analysis (Second Edition). USA: Springer.

Gebru, H., Mohammed, A., Dechassa, N., \& Belew, D. (2017). Assessment of production practices of smallholder potato (Solanum tuberosum L.) farmers in Walaita zone southern Ethiopia. Agriculture and Food Security, 6(1), 3141. https://doi.org/10.1186/s40066-017-0106-8

Hartati, A., \& Setyadji, K. (2012). Tingkat efisiensi faktor produksi pada usahatani kentang di Kecamatan Karangreja Kabupaten Purbalingga Jawa Tengah. Agrin, 16(1), 19-26. http://dx.doi.org/10.20884/1.agrin.2012.16.1.124

Hong, Y., Heerink, N., Zhao, M., \& van der Werf, W. (2019). Intercropping contributes to a higher technical efficiency in smallholder farming: Evidence from a case study in Gaotai County, China. Agricultural Systems, 173, $317-324$. https://doi.org/10.1016/j.agsy.2019.03.007

Kumbhakar, S., \& Lovell, K. (2000). Stochastic frontier analysis. Cambridge: Cambridge University Press.

Maganga, A. M. (2012). Technical efficiency and its determinants in irish potato production: evidence from dedza district, central malawi. African journal of agricultural research, 12(2), 192-197. https://doi.org /10.5897/AJAR11.1463

Makombe, G., Namara, R. E., Awulachew, S. B., Hagos, F., Ayana, M., \& Kanjere, M. (2017). An analysis of the productivity and technical efficiency of smallholder irrigation in Ethiopia. Water SA, 43(1), 48-57. https://doi.org/10.4314/wsa.v43i1.08

Maryanto, M. A., Sukiyono, K., \& Priyono, B. S. (2018). Analisis efisiensi teknis dan faktor penentunya pada usahatani kentang (Solanumtuberosum L.) di Kota Pagar Alam, Provinsi Sumatera Selatan. AGRARIS: Journal of Agribusiness and Rural Development Research, 4(1), 1-8. https://doi.org/10.18196/agr.4154

Novia, R. A., \& Satriani, R. (2020). Analisis efisiensi teknis usahatani padi sawah tadah hujan di Kabupaten Banyumas. Mediagro, 16(1), 48-59. http://dx.doi.org/10.31942/md.v16i1.3389

Nurhapsa. (2013). Analisis efisiensi teknis dan perilaku risiko petani serta pengaruhnya terhadap penerapan varietas unggul pada usahatani kentang di kabupaten enrekang provinsi sulawesi selatan [Desertasi]. Institut Pertanian Bogor.

Rizkiyah, N., Syafrial, S., \& Hanani, N. (2014). Faktor-faktor yang mempengaruhi efisiensi teknis usahatani kentang (Solanum Tuberosum L) dengan pendekatan stochastic production frontier (studi kasus Desa Sumber Brantas Kecamatan Bumiaji Kota Batu). HABITAT, 25(1), 25-31. 